\title{
Ópera ou circo? Teatro e atraso cultural na visão de Lima Barreto
}

\author{
Marcos Vinícius Scheffel*
}

\section{Resumo}

No romance Vida e Morte de M.J. Gonzaga de Sá, Lima Barreto promove uma importante discussão sobre a relação do teatro brasileiro, na cidade do Rio de Janeiro, entre meados do século XIX e início do $X X$, e um suposto papel civilizatório e modernizante atribuído pelos intelectuais brasileiros desse período. Neste artigo, procuro percorrer alguns desses discursos que atribuíam essa função ao teatro para depois comparar com a perspectiva crítica adotada por Lima Barreto ao desvelar o aspecto provisório de nossa modernidade periférica e dependente. Nesse sentido, percorro também trechos do Diário Íntimo e algumas crônicas do autor que se articulam com as questões encenadas em Vida e Morte.

\section{Palavras-chave}

Lima Barreto - teatro e modernidade - teatro e hábitos civilizados.

\section{ZÉ (Ao Pedro II.) - E o senhor? Quem vem a ser?}

PEDRO II - Eu sou o teatro Pedro II, o teatro dos extremos, ou o circo dos saltimbancos, ou a sala da grande ópera. Este ano apareceu por lá uma novidade: as ocarinas sopraram muito, mas não assopraram o público. Depois vieram Fuci, Roles e Mendoros, artistas de primo cartello. Grandes espetáculos a quarenta mil réis por camarote! Lindas óperas, Fausto, Trovador, Aída... Vocês não viram a Aída?

ESPECTADOR - Eu de óperas só conheço A volta de Cogumelo.

PEDRO II - Oh! a Aída! A Aída! Que delírio! Que entusiasmo! O Rio de Janeiro era todo Aída! Que furor! A índole deste povo é essencialmente lírica! (O Rio de Janeiro em 1877, Ato Terceiro, Quadro XIII, Cena V - Arthur de Azevedo e Lino d'Assunção)

A construção de teatros, no Brasil, esteve associada a ciclos econômicos entre meados do século XIX e início do XX, levando cidades como Belém, Manaus (movidas à borracha) e Rio de Janeiro (movido a café) a priorizarem estas construções em detrimento de necessidades mais elementares, fazendo convergir melhorias em torno

\footnotetext{
* Professor da Universidade Federal do Amazonas. Bolsista da FAPEAM e doutorando em Teoria da Literatura (UFSC).
} 
das casas de espetáculo (iluminação, bonde, calçamento), e inserindo-se num circuito de espetáculos internacionais. O Teatro se constituía num símbolo visível e aparente do progresso cultural para as elites emergentes e periféricas, propiciando por algumas horas o apagamento das distâncias com o Velho Mundo, como assinalara Joaquim Nabuco ao associar o teatro às viagens intercontinentais:

[...] todas as horas que tenho vivido na plateia ou nos camarotes, sem contar os minutos nos bastidores, minha carreira de espectador há de preencher talvez o espaço de um ano, o mesmo tempo que tenho passado no mar, e, tanto um como o outro, tenho-os como dos mais bem empregados da vida. (NABUCO, 1901, p. 26).

A construção de um teatro e a possibilidade de se assistir a companhias internacionais deveria oferecer a sensação de fazer parte da nova sociedade (burguesa, liberal, capitalista e técnica) durante o pouco tempo dos espetáculos, que somados, ao longo dos anos, constituíam-se numa escola de civilidade. Essa ideologia, como se pode observar, perpassa vários discursos que Lima Barreto procura problematizar em Vida e Morte.

\section{A função "civilizatória" do teatro: de meados do século XIX ao início do século XX}

Boa parte do que sabe ou se imagina sobre os teatros, na segunda metade do século XIX e início do século XX, vem de crônicas publicadas em jornais e revistas da época, peças de teatro com alusões metalinguísticas, romances, contos e livros de memória. Compõem uma série de textos com autorias e propósitos diversos que se referiam aos espetáculos, a atores e atrizes, às casas teatrais. Os autores desses textos acreditavam num papel civilizatório do teatro, termo que aparece recorrentemente. O historiador, o sociólogo ou crítico literário interessado na questão teatral acaba tendo que recorrer a essa produção espalhada por periódicos e que teve diversos interlocutores, em que se mesclavam informação, opinião, ideologia e imaginação. Joaquim Manuel de Macedo, Machado de Assis e Arthur Azevedo deixaram importantes contribuições a respeito do teatro no Brasil. Antes das constatações de Lima Barreto e de suas personagens acerca do teatro, proponho um breve apanhado das considerações daqueles outros autores sobre as casas de teatro e sua inserção na vida cultural brasileira naquele período.

Na sua vasta produção como cronista, entre 1859 e 1900, Machado de Assis, entremeado aos comentários políticos e aos assuntos da semana, sempre achava espaço para comentar a cena teatral brasileira. Machado afirmava que o teatro se constituía numa escola da civilidade e que num país como o Brasil, carente de escolas, todas elas eram bem vindas. Nas suas Memórias da Rua do Ouvidor (1878), antes publicadas em folhetins da Gazeta de Notícias, Joaquim Manuel de Macedo reiterava esse pensamento da época do teatro como escola da civilidade, mas ressaltava os aspectos daninhos: "O teatro é coisa muito séria. É a mais extensa e concorrida escola pública da boa ou má educação" (MACEDO, 1988, p. 112). As críticas do autor de $A$ moreninha eram direcionadas em especial ao Alcazar, conhecido como Lírico Francês, 
em que se apresentavam trocadilhos obscenos, cancãs, atrizes seminuas, que moldavam o gosto do público e o afastava de bons espetáculos: "A influência epidêmica, perniciosa, palustre do Alcazar foi tal, que o Rossi e o Salveni, tiveram no Rio algumas noites quase sem público" (MACEDO, 1988, p. 112).

Salvo esse aspecto "nocivo", creditava-se ao teatro, ao jornal e à produção literária a função de ilustrar a sociedade e de divulgar os valores burgueses e liberais tão desejados. Segundo Machado, havia em sua época uma preferência do público pelas óperas cantadas em italiano, certo desinteresse pelo teatro dramático e poucos espetáculos nacionais, levando o crítico a tratar com benignidade essa escassa produção a fim de não levar aflição ao aflito. Uma das bandeiras daquele período era a da construção urgente pelo governo de um Teatro Lírico, levando o cronista a emitir uma opinião que deveria opor-se à da grande maioria:

\begin{abstract}
Um teatro lírico tornou-se uma necessidade nesta capital; foi essa necessidade que fez permanecer um teatro Provisório. Mas eu não posso deixar de notar uma singularidade; é o afã com que todos clamam por teatro lírico, e o desdém com que todos se esquecem de um teatro dramático. Entretanto, ninguém porá dúvida que, se o teatro lírico é o agradável, o supérfluo, o teatro dramático é mais que útil, é o necessário. Para reconhecer isto não precisar receber do céu uma grande sagacidade; a inteligência medíocre o reconhece. (Diário do Rio de Janeiro, 10 de janeiro de 1865$)^{1}$
\end{abstract}

O público brasileiro tinha se acostumado com os espetáculos de ópera, que talvez não exigissem tanta atenção como um espetáculo dramático, transformando a ida ao teatro num desfile de roupas e num jogo de ver e ser visto. Essa vida social era importantíssima para que os membros da nobreza, da alta sociedade e de setores médios da sociedade (funcionários públicos, advogados, médicos, militares) pudessem, por exemplo, se conhecer e se casar dentro do seu grupo social. Essa centralidade do teatro na vida da corte brasileira fora observada pelo viajante francês Victor Jacquemont, em 1928, quando teve a oportunidade de assistir à encenação da ópera L'Italiana in Algeri, de Rossini, no Teatro São Pedro de Alcântara. Segundo ele:

O público parecia aborrecer-se muito: no entanto a sala estava cheia e ela é bem grande. [...] As mulheres, ataviadas; os homens em trajes de cerimônia, todos cobertos de condecorações, assumindo a partir dos quinze ou dezesseis anos o ar desdenhoso e enfastiado dos dandys do Regent Street. (JACQUEMONT apud PRADO, 2003, p. 35)

Conforme Machado de Assis, o Teatro Lírico era frequentado por um público mais seleto, sendo o ingresso deste teatro mais caro que o do Teatro de São Pedro, onde se representavam os dramas e as comédias. Quer dizer: quem frequentava o lírico era associado a um lugar melhor na sociedade, como ironizava Machado: "Nem todos terão treze mil réis para dar por uma cadeira do Teatro Lírico. Eu tenho cinco, faltam-me oito. Podia ir ao Teatro de São Pedro, onde a cadeira custa menos; mas eu

${ }^{1}$ As crônicas são citadas de arquivos digitais, por isso mantenho a data e o periódico em que foram inicialmente publicadas para facilitar a consulta. 
só entendo italiano cantado, e a Duse-Checchi não canta" (Gazeta de Notícias, 16 de julho de 1885). Mais adiante, o cronista afirmava, com ironia, que só assistia a óperas, pois as outras peças ou eram demasiado tristes ou demasiado alegres e ele não queria cair num daqueles dois extremos. O interesse pelas óperas levava inclusive alguns cantores nacionais a se arriscarem na produção de espetáculos de qualidade duvidosa:

Sobre notas tivemos esta quinzena duas espécies, as falsas e as da ópera italiana, - um velho calembour, rafado, magro e decrépito que há de viver ainda muito tempo. Por quê? Porque acode logo à boca.

Ópera italiana é uma maneira de falar. Reuniram-se alguns artistas, que vivem há muito entre nós, e cantavam o Trovador; prometem cantar algumas óperas mais.

São bons? Não sei, porque não os fui ainda ouvir; mas das notícias benignas dos jornais, concluo que, - um não cantou mal, - outro interpretou bem algumas passagens, o coro de mulheres esteve fraquinho e o de homens foi bem sofrível e não se achava mal ensaiado.

Que concluir depois, senão que o público fluminense é uma das melhores criaturas do mundo?

Ele ouviu Stoltz, Lagrange, Tamberlick, Charton, Bouché e quase todas as celebridades de há anos. Benévolo e protetor do trabalho honesto, não quer saber se os atuais cantores lhe darão os gozos de outro tempo; acode a ampará-los e faz bem.

Balzac fala de um jogador inveterado e sem vintém que, presente nas casas de tavolagem, acompanhava mentalmente o destino de uma carta, parava nela um franco ideal, ganhava ou perdia, tomava nota das perdas e ganhos, e enchia a noite desse modo.

O público fluminense é esse jogador, sem vintém; ficou-lhe o vício musical sem os meios de o satisfazer. Vai à tavolagem, acompanha o destino de uma nota, reconhece às vezes que é falsa, mas troca-a mentalmente por outra que ouviu em 1853. (Ilustração Brasileira, 1 de julho de 1876)

A crônica de 1876 relembrava renomados artistas internacionais da época que se apresentaram nos palcos do Teatro Provisório - Rosina Stoltz, Ana Lagrange, Enrico Tamberlick, Charton, Bouché -, atribuindo o sentimento benigno do público fluminense para com a ópera improvisada pelos atores brasileiros à memória viva das apresentações do passado no Provisório. Para o cronista, o público assistia a um espetáculo de qualidade duvidosa, mas lembrava de outro de duas décadas atrás. Como o jogador sem dinheiro de Balzac que apostava o que não tinha, o público brasileiro satisfazia-se com o fato de comparecer ao teatro independente da qualidade da ópera e, se o espetáculo não era tão agradável, comprazia-se com as recordações de outros tempos. Conclui-se que o teatro constituía-se num espaço de sociabilidade, exibição e de apuração da civilidade num país acostumado à chatinagem e à veniaga com escravos, como afirmava Gonzaga de Sá, e que queria se meter em outros negócios que pudessem polir nossa civilização. Dentro da perspectiva do teatro como escola da civilidade, Machado de Assis associava o interesse do brasileiro pelo teatro à moda, pois ambos tinham suas regras ditadas por Paris: "Em matéria teatral, orçamos pela alfaiataria: é de Paris que nos chegam as modas. Paris teatral é como os seus grandes depósitos ou armazéns de roupas: tem de tudo, para todos os paladares, desde o mimoso até o sangrento passando pela tramóia" (Ilustração Brasileira, 15 de novembro de 1877). 
Passadas algumas décadas, os espetáculos teatrais no início do século XX mantinham no Rio de Janeiro o prestígio, sendo comuns turnês de companhias estrangeiras vindas de Portugal, Espanha, Itália e França, que se aproveitavam dos avanços da navegação que tinha reduzido pela metade o tempo das viagens entre a Europa e a América. As especulações financeiras da época do Encilhamento, os lucros obtidos com o café, o crescimento da máquina burocrática na capital Federal criaram de uma hora para outra um público, diminuto, porém interessado nas coisas do teatro. A maioria dos jornais contava com uma coluna dedicada exclusivamente à arte dramática, com programação, resenha, crítica, reclamações e histórias curiosas que ocorriam nas salas de apresentação. Na primeira coluna do ano de 1904 de sua seção semanal sobre o Teatro, que manteve na Gazeta de Notícias entre 1895 e 1908, Arthur Azevedo fazia um balanço do número de peças apresentadas no ano anterior: "houve, no Rio de Janeiro, nos teatros propriamente ditos, 1006 espetáculos, sendo: 202 no Recreio Dramático, 234 no S. José, 223 no Apollo, 106 no Lucinda, 95 no Lírico, 54 no S. Pedro de Alcântara e 2 no Éden-Lavradio" (AZEVEDO, 2009, $07 / 01 / 1904)^{2}$. Ou seja, uma incrível média de mais de dois espetáculos por noite, numa cidade com 800 mil habitantes, sendo que 200 mil deles em condições precárias, e um público espectador que não deveria chegar a $3 \%$ da população. ${ }^{3}$ Eram muitas as casas teatrais, porém de qualidade questionada pelos artistas que reclamavam da iluminação, da acústica, do comportamento do público ou da ausência dele. Mesmo num teatro considerado sofisticado, como o Lírico Fluminense, eram comuns cenas grotescas na audiência:

\begin{abstract}
A molecagem das torrinhas é que está cada vez mais insuportável. E a polícia cruza os braços diante daquele escândalo que tanto depõe contra a nossa civilização.

Ontem um estrangeiro, que pela primeira vez tinha a desgraça de assistir a um espetáculo no Rio de Janeiro, ficou pasmado diante da gritaria da garotada.

- Se isto é no Lírico, disse ele, que será nos demais teatros!

- Não admira, observou ele, que o pobre Grani esteja com tanto medo. Uma sala tão turbulenta amedronta o artista mais corajoso! Este público servirá para estimular um toureiro, não um cantor. (AZEVEDO, 2009, 10/6/1897)
\end{abstract}

Em suas crônicas, versando sobre o teatro, Arthur Azevedo apontava estas situações que depunham contra a nossa civilização: as cadeiras desconfortáveis, a algazarra da molecagem das torrinhas, o barulho vindo do exterior do teatro, a promiscuidade nas galerias, os chapéus das grandes damas que atrapalhavam a visão do espetáculo e a insuficiência de bondes para as casas teatrais, fazendo com que os cocheiros cobrassem preços exorbitantes:

Uma das causas do afastamento do público dos nossos teatros, são as massadas a que obrigam as dificuldades de condução. D'antes, para evitar a demora do bonde, as famílias voltavam de carro, os cavalheiros de tilburi, e isso não lhes custava um grande sacrifício. Hoje, só as pessoas abastadas podem 'rouler voiture'; os

\footnotetext{
${ }^{2}$ As crônicas se encontram em CD junto com o livro, por isso mantenho a data de publicação para facilitar a consulta.

${ }^{3}$ Em meio às polêmicas da construção do Teatro Municipal, Lima Barreto afirmava, em 1911, que não havia no Rio de Janeiro um público de 20 mil pessoas ricas para justificar a construção de um grande teatro (BARRETO, 2004, p. 71).
} 
cocheiros de praça tornaram-se de uma exigência feroz e sustentam que depois de certas horas da noite não há tabela: o preço é o que eles quiserem - e não há nada mais desagradável que discutir com cocheiros. (AZEVEDO, 2009, 16/01/1902).

A imagem de pessoas vestidas com luxo e pompas tendo que se locomover para o teatro de bonde, quem sabe dividindo espaço com aquele um quarto da população de "pés no chão", ou em carros de praça precários e tendo que discutir o preço com cocheiros depois de assistir a uma ópera italiana é representativa daquela "modernidade" problemática. A existência de uma vida cultural noturna, numa sociedade que deseja estar pari passu com a Europa, denunciava deficiências dos transportes, da iluminação e do policiamento da cidade. Em meio a todas essas dificuldades, os administradores dos teatros procuravam impor algumas normas e solicitavam casaca ou smoking para áreas mais "nobres". Trajes que por vezes viravam motivo de chalaça dos jovens das galerias e torrinhas, constituindo-se num espetáculo à parte, dando assunto aos cronistas teatrais, como nesta suposta carta recebida por Arthur de Azevedo de um comendador barrigudo:

Não vos parece, meu caro Sr. A. A., extravagante essa opinião de que os espectadores das torrinhas (estudantes ou não) tenham o direito de ridicularizar, apupar e envergonhar os comendadores que sejam barrigudos ou os barrigudos que sejam comendadores? Não creio que ter barriga e comenda seja uma ignomínia social que impeça qualquer cidadão honesto de ir ao teatro sem o receio de ser vaiado. Peço-vos que digais alguma cousa a esse respeito no vosso folhetim d'A Noticia. - Um comendador barrigudo. (Gazeta de Notícias, 20/06/1898).

Talvez essa balbúrdia toda, narrada pelos cronistas brasileiros da época e por viajantes que se encontravam no Brasil, se explicasse pela natureza de alguns espetáculos que eram apresentados nestas mesmas casas (números de circo, hipnotismo) que tanto agradavam ao público, ou o aspecto improvisado destas casas que não foram projetadas para esse fim como o Teatro Lírico que "por mais que o atamanquem, não consegue disfarçar o seu aspecto de hipódromo" (AZEVEDO, 2009), ou se explicasse pelo ecletismo do público - deseducado nos Cafés Concerto. O Teatro Lírico que substituíra em importância o Teatro Provisório (derrubado em 1875) era alvo de constantes comentários por lembrar um circo, possuindo inclusive trapézios no alto do seu teto, como observou a celebrada artista Gabriela Réjane, da companhia Antoine, que viera em 1902 para o Brasil: - "Mais, c'est un cirque!" 4 (EDMUNDO, 2003, p. 266).

Fora essas questões, o Teatro continuava exercendo uma forte influência nos hábitos sociais das classes que podiam frequentá-lo, ditando modas, impondo costumes e criando distinções sociais entre os diferentes segmentos que assistiam às peças. Lima Barreto, que viveu boa parte de sua juventude neste período, dizia-se pouco afeito às coisas do Teatro. Nem por isso, Lima Barreto deixou de manifestar certas implicâncias: com Arthur Azevedo, que, no seu entendimento, tentara impor-se como dono da opinião acerca dos assuntos do teatro (BARRETO, 2004, p. 475-479); com a municipalidade que armou "um teatro cheio de mármores, de complicações luxuosas, uma teatro que exige casaca, altas toilettes, decotes, penteados, diademas,

\footnotetext{
${ }^{4}$ Lima Barreto atribui a frase ao dono da Companhia Teatral e não à atriz.
} 
adereços" (BARRETO, 2004, p. 71). Para Lima Barreto, o Rio de Janeiro não deveria ter investido num grande teatro no centro da cidade, pois esse estava fadado a ficar vazio, desestimulando os atores e inviabilizando os espetáculos que jamais se pagariam. Lima Barreto achava que seria mais interessante investir em pequenas salas em diferentes pontos da cidade, inclusive nos subúrbios, oferecendo espetáculos variados e que, aos poucos, educariam o público. Obviamente, numa capital que passava por medidas urbanizadoras, voltadas a dar um aspecto mais moderno à cidade, a ideia de Lima Barreto não encontrava o menor eco. Por outro lado, enquanto escritor, os espetáculos e os desempenhos de atores e atrizes serviam de termo de comparação à escrita literária, como ocorre numa anotação de 30 de janeiro de 1905:

Domingo, fui ao Papa Lebonnard, drama em quatro atos de Jean Aicard. É um drama de moldes velhos, feito por um autor novo e de talento. A Lucinda, a minha querida Lucinda, um gosto que foi meu pai quem mo deu, fez o papel com uma sobriedade, com uma elevação, que admira em língua portuguesa.

A Lucinda não tem ênfase e com poucos recursos de fisionomia ela tira um partido excepcional. É como um escritor de pequeno vocabulário, mas com grande conhecimento da sintaxe e um grande sentimento da língua. O Cristiano não é lá essas coisas, esforça-se, trabalha, sabe, mas, como disse um português, não tem o teatro no peito. O Ferreira é melhor; entretanto, com se sentir nele um ator inteligente, vê-se que Ihe falta a observação do tipo que representava, um nobre, um marquês. (BARRETO, 1956b, p. 95)

A ida ao teatro acontecera logo após uma leitura feita para o amigo e escritor Alcides Maia dos primeiros capítulos de um romance que escrevia, ${ }^{5}$ onde ouviu "pequenas observações, emendando, que eu aceitei" (BARRETO, 1956b, p. 95). A visita ao amigo - inteligente, ilustrado, estudioso, delicado de sentimentos (BARRETO, 1956b, p. 95) - deve tê-lo posto num momento de reflexão sobre a arte do romance e ele logo procura associar a lição ao espetáculo assistido, reconhecendo na aclamada Lucinda Simões a qualidade de tirar com poucos recursos de fisionomia um partido excepcional, comparando-a a um escritor de pouco vocabulário, mas com sentimento de língua. Não seria essa a imagem que Lima Barreto fazia de si ou a imagem desejada para si em termos de uma produção literária futura que já se insinuava nas páginas da intimidade e nas crônicas? Em contrapartida, a atuação de Ferreira de Sousa pecava pela falta de entendimento do tipo que representava: um nobre, um marquês. Em linhas gerais, Lima Barreto refletia sobre a necessidade da síntese e do estudo do tipo como elementos essenciais para a criação artística. O teatro oferecia ao autor a possibilidade de, no espaço sintético de uma sala de apresentação, colocar em contraste parcelas significativas da sociedade brasileira do período, articulando, em dois tempos distintos, o gosto pelo teatro como um traço de união que podia oferecer contrastes, continuidades, e a estagnação da vida política e cultural do Brasil. Ou seja, a desejada função de escola da civilidade tinha o reverso da moeda, pois a sede de

\footnotetext{
${ }^{5}$ Em nota a esta passagem do Diário, Francisco de Assis Barbosa lembra que nesse período Lima Barreto tinha prontos três capítulos de Clara dos Anjos (primeira versão incompleta), mas que a leitura deve ter sido dos capítulos iniciais de Recordações (BARRETO, 1956b, p. 113, nota 13).
} 
competição e distinção social ganhava força naquele espaço, deixando mais evidentes os aspectos periféricos e dependentes do país.

Em crônica de 1903, intitulada "Ópera ou Circo?", publicada na Revista Tagarela, Lima Barreto comentava a frase do Sr. Antonie, diretor da Companhia Teatral de Gabriele Réjane, sobre o aspecto de circo do Teatro da Velha Guarda. Contextualizando historicamente, esse teatro fora inaugurado em 20 de junho de 1871, tendo sido utilizado durante mais de uma década pelo Circo Olímpico (1857). Em 1875, por despacho Imperial, passou a se chamar Teatro Imperial D. Pedro II. Em 1890, devido à proclamação da República e para ocultar suas origens monárquicas, teve seu nome mudado pela última vez para Teatro Lírico Fluminense - o que não impedia que a população fluminense o chamasse de D. Pedro II. Essas sucessivas mudanças de nomes de um estabelecimento ou de um espaço público (ruas, praças) foram motivadas por episódios históricos marcantes entre meados do século XIX e início do século XX, como a Guerra do Paraguai. Diversos desses nomes novos existiam apenas para municipalidade, pois a população preferia a denominação consagrada pela tradição. ${ }^{6}$ Ironicamente, Machado de Assis tratou desta questão em Esaú e Jacó, romance de 1904 (ASSIS, 1999, p. 91-93, p. 112-117). Nele, o Conselheiro Aires é consultado por Custódio, dono de uma confeitaria chamada Império, sobre o que fazer com o nome do estabelecimento agora que havia um novo regime político e a antiga placa tinha sido reformada, por azar, no dia da Proclamação da República. A conversa entre o velho Conselheiro e o comerciante é repleta de ironias, questionando as alterações superficiais, sintetizadas na frase do Conselheiro: "Pintura nova em madeira velha não vale nada" (ASSIS, 1999, p. 91-93, p. 115). 0 Conselheiro Aires dá ao confeiteiro uma série de sugestões para resolver o dilema, como inscrever a data da fundação abaixo do nome da confeitaria; dar o nome da rua ou o seu próprio nome; chamá-la de confeitaria do Governo ou Império das leis (em letras minúsculas). Todas as sugestões apontam para a fragilidade e desconfiança em relação ao regime recém-instaurado e a possibilidade iminente de novas mudanças.

De modo semelhante, o Teatro Lírico Fluminense servia para Lima Barreto como um sintoma da superficialidade dessas alterações ou, na fórmula sintética do Conselheiro Aires, pintura nova em madeira velha. Voltando à crônica de 1903, Lima Barreto comentava alguns aspetos pitorescos do Teatro da Velha Guarda como as barras de ferro hercúleas, que atravessavam a sala, lado a lado, que denunciavam o antigo uso circense do espaço e o detalhe de uma imagem em que heráldicos dragões sopesavam o espadagão da república que tão bem se justapôs à esfera armilar do Império. A junção ocasional ou por descuido dos administradores do teatro daqueles dois emblemas denunciava o entrelaçamento entre o presente republicano e o passado monárquico, pois aquela casa de espetáculos continuava a receber os setores dirigentes do país, que em essência não tinham mudado. Tinham apenas sofrido acréscimos de setores emergentes devido às necessidades da cidade letrada. O Teatro

${ }^{6}$ Pedro Lira, em sua História de D. Pedro II, registra uma série de mudanças de nomes de ruas ocorridas devido à Guerra do Paraguai: de Rua Matacavalos para Riachuelo, de Rua do Cano para Visconde do Rio Branco (LIRA, 1977, p. 35). Com o advento da República, a rua do Ouvidor, por exemplo, foi rebatizada com o nome de Moreira César, que não caiu no gosto popular (EDMUNDO, 2003, p. 40). 
da Velha Guarda revelava um interessante jogo de duplos (ópera/circo, monarquia/república) que se confundiam e se mesclavam, sendo que a única diferença existente entre os pares era a designação nova que se opunha à antiga. Era essa dualidade que sintetizava movimentos típicos de nossa vida social, como explicava o cronista:

Creio que me expliquei mal. Naturalmente acham os períodos acima nebulosos por demais; mas exemplificar-me-ei para melhor compreensão.

Supondo: largo do Machado, num barracão de quintal, canta-se a Marcha de Cadis, se está o 'high-life' de casaca - que é? É o Lírico.

Mas por que é Lírico? Porque... Porque... Porque se está de casaca... Imaginai: no bonde (de ceroula ou não), viajam uma senhora e cavaleiro, ambos trajando vestuários de preço, a soberba capa da senhora faz pendante ao elegante sobretudo do senhor; ao vê-los perguntareis:

- Que diabo! Tão ricamente vestidos em bonde de 200 rs.! Que diabo! Que será?

- É o Lírico, respondo eu. Compreenderam?

É o Lírico sob o aspecto... diga-se... sob o aspecto subjetivo. Sob o aspecto objetivo o símile é perfeito; vejamos: em começo é pleno capinzal, ao depois umas paredes adelgaçam-se formando o barracão de circo, mais depois uma fachada pretensiosa acaba a edificação - eis o Lírico. (BARRETO, 2004, p. 66-67)

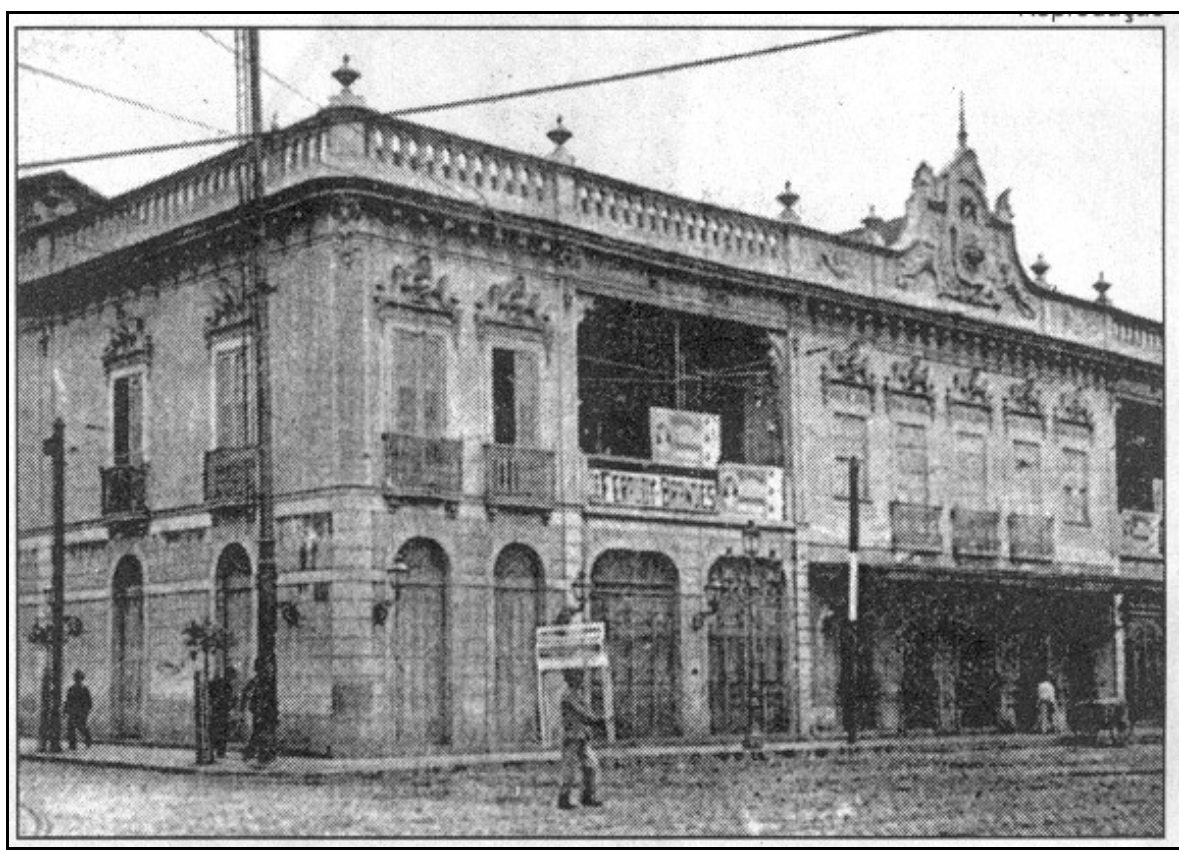

Imagem 1 - Teatro Lírico Fluminense, inaugurado em 1871. Teve vários nomes: Teatro Pedro II, Teatro da Velha Guarda. Antes de ser teatro, o prédio abrigava o Circo Olímpico

Tal dualidade estendia-se aos espectadores que, apesar de frequentarem aquele espaço sofisticado e de pertencerem aparentemente a uma elite, não podiam ocultar alguns índices de pobreza e subdesenvolvimento típicos de um país periférico: assistindo a um espetáculo internacional, vestidos com uma elegância importada ou 
copiada da Europa, mas chegando num bonde de 200 réis de ceroula ou não. ${ }^{7} \mathrm{~A}$ expressão sem ceroulas, insinuada em de ceroula ou não, já significava naquela época desprovido de dinheiro. A diferença dos pés-no-chão, citados por Bilac em crônica de 1907, para os sem ceroula de Lima Barreto é evidente, mas deve ser destacada: os primeiros pertencentes aos grupos populares não podiam esconder a sua condição e tinham seu trânsito normatizado nas ruas centrais da cidade, enquanto o segundo grupo desfilava livremente pelos ambientes elegantes, colhendo frutos desta sua exposição (uma negociata, um casamento vantajoso, um tema para uma crônica mundana). Os parênteses usados na crônica parecem destacar essa ocultação da falta da peça íntima sugerida pelo jogo linguístico, detalhe que põe a nu o jogo sutil e, por vezes, imperceptível das aparências. Num teatro que não era teatro, uma elite que talvez não fosse elite (por estarem na periferia do capitalismo e tendo em vista os índices exteriores de pobreza, simbolizados no uso do bonde) procurava manter a pose. O mais importante neste jogo era o figurino e a convicção de estar desempenhando o papel com propriedade. O cronista procura destacar que esse sentimento da pose, palpável no interior do teatro, poderia servir como chave de leitura para outros aspectos da vida social do país. O teatro constituía-se num microcosmos, ou seja, a representação do "essencial de maneira a suscitar a ilusão de que a vida toda esteja representada na sua expressão integral" (LUKÁCS, 1968, p. 67), técnica essencial do romance de feição realista. Microcosmos representativo de um sentimento que obsedava o país e que atendia por outros nomes: mania aristocrática, desejo de lustro, cosmopolitismo, high-life, vida elegante, hábitos civilizados. O Lírico Fluminense reunia e sintetizava setores importantes da sociedade brasileira que para lá convergiam:

E o circo? Existe sempre. Em estando a sala cheia, existem lá: malabaristas de câmbio, acrobatas dos códigos (francês, inglês, etc.) écuyers gentis, no patrimônio, equilibristas da corda bamba da vida, e por fim, uma coleção de animais exóticos: papagaios parlamentares; macacos velhos que não metem mão em cumbuca; hidras da oposição; serpentes da intriga; patativas do norte (vulgo meninos prodígios); uniolho biográfico (animal da Polinésia onde o mar toca piston); etc. (BARRETO, 2004, p. 66-67)

Vendo essa fauna exótica, Lima Barreto - que sequer havia esboçado os projetos de seus romances, e que por esse período ainda frequentava a escola Politécnica, tendo ido ao Lírico Fluminense entre aqueles jovens que faziam zoada e ironizavam as falsas aparências das casacas mal-ajambradas - deve ter percebido o poder de síntese que aquele espaço poderia the propiciar. Pelos seus corredores escuros e nas suas cadeiras desconfortáveis passaram e continuavam passando comerciantes, políticos, jovens vindos do interior, escritores que compunham a dinâmica da sociedade, incluindo a dinâmica da estratificação social nos diferentes setores do teatro: camarotes, cadeiras, torrinhas e corredores escuros (semelhantes às ruas da cidade, por onde todos circulavam).

7 Estes bondes tinham seus bancos "forrados com capas brancas amarradas nos balaústres por meio de cadarços para as temporadas líricas" (DUNLOP, 1972, p. 42). 


\section{O teatro na visão de Gonzaga: dependência e atraso cultural}

Os diálogos entre Gonzaga de Sá e Augusto Machado ocorrem no início do século $X X$, não havendo, contudo, um ano preciso inscrito na narrativa. Sabe-se que: 1) é o período da construção da avenida Beira-mar, que teve suas obras iniciadas no começo da gestão de Pereira Passos (1902-1906), por onde as personagens passam durante um passeio; 2) o Barão de Rio Branco é ministro das Relações Exteriores (1902-1912) - chamado com menosprezo por Gonzaga de Sá de Juca Paranhos; 3) a "Explicação Necessária", texto assinado por Augusto Machado que precede a narrativa, é de 1906. Outro elemento textual aponta para um período próximo a 1903 ou 1904, como o ano em que as duas personagens iniciam a amizade: uma notícia de jornal da Gazeta de Uberaba, lida por Gonzaga de Sá, relatando a chegada do gado zebu ao Brasil. ${ }^{8}$ A idade de Gonzaga de Sá não é fornecida por Augusto Machado, responsável pela "biografia" do amigo. Sabe-se que ele estava no funcionalismo público desde antes da proclamação da República e que fora pego de surpresa no 15 de novembro: '"Seu' Gonzaga, hoje não se trabalha; o Deodoro, de manhã proclamou a República do Campo de Sant'Ana:- Mas qual? - perguntou" (BARRETO, 1956a, p. 47-48).

Afora esses dados espalhados ao longo da obra, obrigando o leitor a juntar tais fragmentos, o plano do romance, que se encontra junto com as anotações da intimidade, traz uma data possível para o nascimento de Gonzaga: 1850. Data que não se confirma no romance, pois numa breve fala Escolástica revela que seu irmão contava com 11 ou 12 anos na época do benefício de Rosina Stoltz, ${ }^{9}$ em 1852, logo teria nascido por volta de 1840, justificando o aspecto envelhecido da personagem na ótica do narrador: "Era Gonzaga um velho alto, já não de todo grisalho, mas avançado em idade, todo seco [...] A sua tez era amarelada, quase dessa cera amarelada de certos círios". (BARRETO, 1956a, p. 36). Destaca-se, nos planos da obra, o fato de que todas as idades das personagens foram calculadas tomando como referência as apresentações no Teatro Provisório da cantora italiana de ópera Rosina Stoltz, em agosto de 1852, e do pianista americano Louis Moreau Gottschalk.

Outro dado dessa problematização é a própria estrutura do romance, quase sem enredo e que se articula por meio de diálogos entre as personagens, aproximando-se da técnica comum ao teatro. Talvez por isso a desnecessidade de citar a idade de Gonzaga, já que o seu aspecto envelhecido e os objetos de seu escritório são reveladores de sua idade, da condição social e da tentativa de ilustração. Além desse caráter dialogal e cênico, as duas personagens centrais quase monopolizam a cena, tendo as demais personagens o papel de figurantes inexpressivos (Escolástica, Alcmena, Xisto Beldroegas, Aleixo Manuel, a Comadre). A cidade, o escritório, a casa de Gonzaga configuram-se como cenários possíveis e com elementos significativos rapidamente marcados, como se fosse uma rubrica do autor para o encenador ou para a rápida visualização do leitor. Visualidade latente na cena do jantar em que os movimentos e ações das personagens são marcados por objetos como o piano e os

\footnotetext{
${ }^{8}$ Essa matéria de 1903 pode ser consultada no Arquivo Histórico de Uberaba.

${ }^{9}$ Os benefícios eram festas dedicadas a artistas visando arrecadar fundos para os mesmos. Tratava-se de uma prática comum tanto para os artistas brasileiros como para os estrangeiros.
} 
bicos de gás, elementos de fácil utilização numa cena teatral e de forte poder simbólico:

\begin{abstract}
Gonzaga pôs a olhar interrogativamente. A sala estava quase em treva completa, na indecisão dos traços de sua cabeça, eu só via o seu grande olhar que me envolvia todo, respirando vaticínios de simpatia. Dona Escolástica, ergueu-se da cadeira, olhou um pouco a janela, depois voltou-se e disse, destacando palavra por palavra.

- Está escuro. Acende as luzes, Manuel.

E os bicos de gás foram acesos vagarosamente. O velho piano Érard, de cauda, monstruoso, muito grande, surgiu todo inteiro na sala iluminada, como um animal fantástico. Mal as luzes brilharam, a paz externa quebrou-se. Houve um pequeno sussurro e a vida das coisas continuou. (BARRETO, 1956a, p. 99)
\end{abstract}

O romance pode ser encarado como um espetáculo mínimo, com poucos cenários: a secretaria de Cultos, a cidade em processo de urbanização, a casa de Gonzaga, a sala do funeral de Romualdo e, por fim, o próprio Teatro Lírico Fluminense. Local de duas cenas ou diálogos do romance que se aproveitam do teatro como ponto de articulação entre passado (monárquico) e presente (republicano). Do passado, as memórias de Gonzaga e Escolástica sobre os espetáculos marcantes do antigo Teatro Provisório (Capítulo VIII - O jantar). Do presente, uma ida dos dois amigos ao Teatro Lírico Fluminense, que antecede a morte de Gonzaga (Capítulo XI - Era feriado nacional). Ambas as cenas/diálogos articulam-se com a crônica de 1903 e com as anotações do Diário. O primeiro diálogo ocorre na casa de Gonzaga quando este recebe, em companhia da irmã Escolástica, o amigo Augusto Machado para jantar. O velho piano é o ponto de articulação das memórias indeléveis do Teatro Provisório de Gonzaga e de Escolástica:

\footnotetext{
- Dona Escolástica não toca?

Esta pergunta eu lhe fiz por mera polidez, visto que a sua avançada idade já a devia ter separado do velho instrumento.

- Há trinta e tantos anos que não.

- Desgostou-se?

- Desde que ouvi o Gottschalk não tive mais ânimo de me sentar ao piano. Só quem o não ouviu!... Era macio, que cousa! Tinha não sei o que nas mãos...

$\mathrm{E}$ a velha senhora queria achar palavras, modismos que transmitissem a impressão que Ihe fizera o pianista e suas músicas; e, como esforço, o seu olhar de esmeralda tomou mais brilho, correndo por ele uns lampejos de mocidade breves e apagados.

- Nunca ouviste peças dele? perguntou-me Gonzaga de Sá.

- Uma ou outra.

- Merecia ouvi-las. São bem diferentes da música dos mestres europeus - seca, sem raízes na nossa sensibilidade americana. O Gottschalk era fantástico, dolente, impetuoso... Aqui, ele provocou um delírio geral.

- Gostavas muito, não era, Manuel? Lembro que foste a todos os concertos com teu pai. Falavas muito na "Morta", no "Poeta"

-... na "Savana", na "Bamboula", nos "Olhos Crioulos", concluiu Gonzaga de Sá. Que entusiasmo gerou! E estávamos em guerra com o Paraguai... Não foste, Escolástica, ao concerto-monstro? (BARRETO, 1956a, p. 99-100)
}

A alusão ao pianista Luis Moreau Gottschalk - que já constava desde as primeiras anotações da obra - não é fortuita. Ele era descendente de criollos haitianos 
e de um negociante judeu de Londres, viajou por muitos países latino-americanos e morreu no Rio de Janeiro em 1869, alguns dias após passar mal durante uma apresentação no Teatro Lírico Fluminense, quando executava uma peça romântica intitulada "Morte". No plano da obra, antes de morrer, Gonzaga pediria para sua irmã Escolástica (que no romance vira sua tia) para que tocasse a Bamboula, música do célebre pianista americano inspirada no tambor africano tocado pelos escravos americanos. A cena da morte na versão final é trocada por Gonzaga indo ao jardim, pegando uma flor e morrendo sem dramaticidade. Gonzaga faz referências às músicas de Gottschalk e mantém especial estima pela Bamboula, que talvez estivesse ali para apontar um ponto possível de convergência na criação artística entre as culturas latino-americanas (o pianista criollo), europeia (o piano e a música clássica) e africana (a recriação artística a partir dos sons do tambor africano), como dá a entender quando aconselha Augusto a ouvir o pianista americano: "Devia ouvi-las. São bem diferentes da música dos mestres europeus - seca, sem raízes na nossa sensibilidade americana" (BARRETO, 1956a, p. 100). O pianista americano, de ascendências étnicas plurais, com sangue criollo, dominando um instrumento da cultura europeia, assim como era o romance, não deixava de ser uma imagem oportuna para Augusto Machado e para o próprio Lima Barreto. Tudo se resumia a apropriar-se desses instrumentos e colocar neles traços distintivos da cultura criolla, da cultura mestiça que havia se desenvolvido na América por obra da colonização, sem negar a cultura europeia. Essa ideia é confirmada pelo próprio Augusto Machado, personagem mulato, que por um lado sente-se ligado à sua ascendência africana, mas que não negava os aprendizados dos mestres europeus (pensadores, romancistas, historiadores, filósofos) que o ajudaram a pensar sobre sua própria condição. O pianista criollo, termo que no Brasil passou a designar pejorativamente apenas os negros, ${ }^{10}$ fora aplaudido $e$ admirado por uma sociedade escravocrata que deixara uma herança de preconceito e distinções sociais baseadas na raça.

\footnotetext{
10 O dicionário Houaiss registra como um dos primeiros usos do termo "cria" ou "escravo", confirmando depois a aplicação do termo para descendentes de europeus nascidos nos países hispano-americanos e para línguas mistas nascidas nestes países. O dicionário Aurélio registra primeiro a associação do termo ao indivíduo negro e em segundo lugar o sentido original do termo: indivíduo branco, nascido nas colônias europeias, particularmente na América. Os dois dicionários associam o termo a produtos (cigarro) e criações (galinhas, cavalos) que não vêm de fora. Neste último sentido, associa-se à ideia de sem raça definida. Segundo Antenor Nascentes (in: Houaiss), o termo originou-se provavelmente do verbo do latim creaturu particípio do futuro ou do verbo latino creare 'criar' (creaouro > creooro > criouro > crioulo), usado para designar 'o negro nascido nas colônias'; deve ter-se difundido através do espanhol criollo (1595). Quanto à distorção do termo criollo no Brasil, ela é comentada por Lima Barreto na crônica "Sestros Brasileiros" (TC2, p. 263-266), de 1920. É interessante notar que a crônica parte de duas matérias de jornal, uma de 1905, guardada com cuidado por Lima Barreto, e outra de 1920, ou seja, estes dois incidentes, separados temporalmente, relacionavam-se a uma mesma perspectiva histórica, compunham uma cadeia de leitura da questão racial no Brasil. Na primeira matéria, Rafael Pinheiro, descrito como o pior arrivista possível, narrava o mal-estar que causou num grupo de brasileiros que acompanhava o maestro Puccini pelas ruas do Rio de Janeiro, quando o maestro italiano observou que havia muitos negros no Brasil, causando um riso doloroso na comitiva brasileira que não queria que um estrangeiro achasse que o país era uma terra de negros. Na segunda matéria de 1920, o Rio Jornal se indignava com o historiador Nicolás Estévanes, autor de Resumen de la Historia de América, por este afirmar que na Revolução Pernambucana de 1817 houve a participação decisiva de criollos (que para os articulistas do jornal significava negro). Lima Barreto observava a impropriedade desta tradução já que crioulo, segundo o dicionário, referia-se à "pessoa de raça branca, nascida nas colônias europeias de ultramar, especialmente da América". As alusões a Gottschalk, constante desde os rascunhos da obra, deviam cumprir essa função crítica.
} 


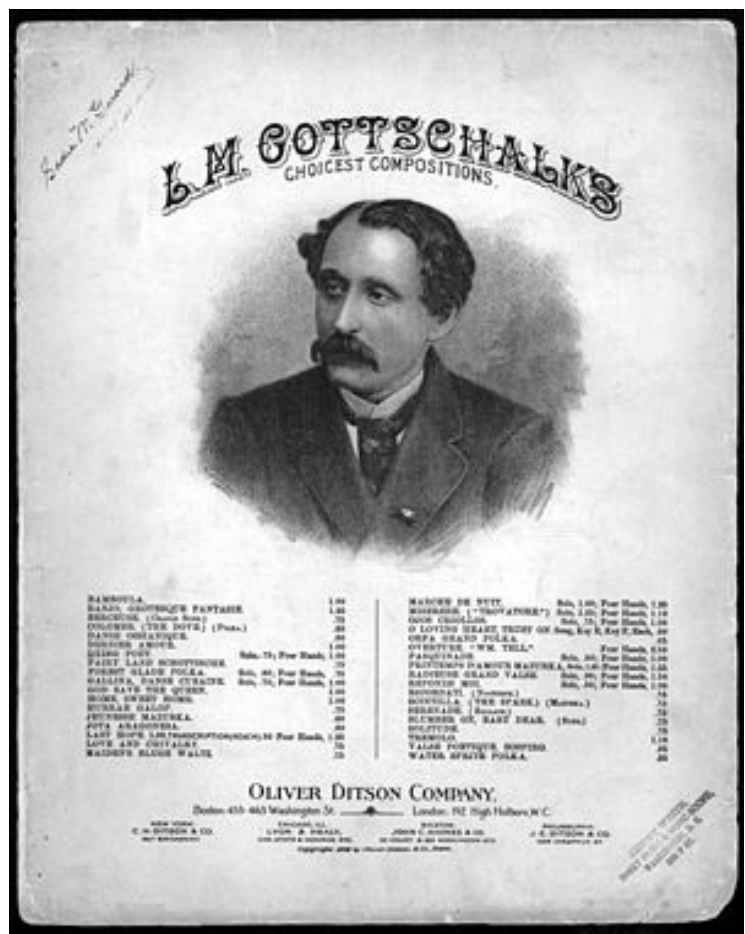

Imagem 2 - Retrato de Louis Moreau Gottschalk para a publicação da música $O$ poeta morto para piano.

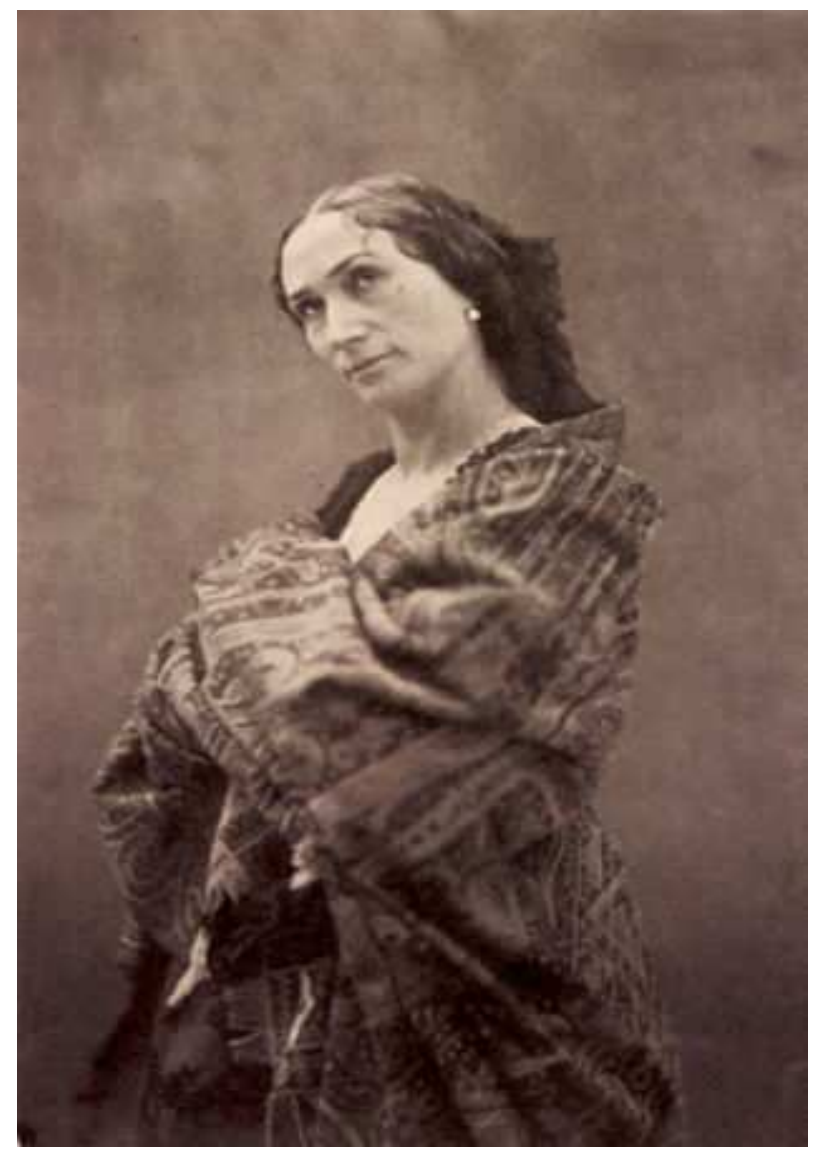

Imagem 3 - Rosine Stoltz. Foto de Nadar 
Já a Italiana Rosina Stoltz simbolizava a preferência das audiências brasileiras pelas óperas, pelo teatro lírico. Para Gonzaga de Sá, o Teatro Lírico constituía-se numa verdadeira mania nacional e fora pensado por D. Pedro II como um espaço voltado para educação, encontro e perpetuação (por meio dos casamentos) da elite e da nobreza brasileira, que na ausência de palácios e salões de luxo podia desfrutar das óperas, vestir-se bem e ostentar os lucros obtidos com o seu produto de exportação, o café. Vendia-se café e importavam-se produtos culturais de fácil assimilação por uma audiência pouco exigente e despreocupada como o espetáculo que acontecia no palco:

\begin{abstract}
- Influência do Império. O Provisório custou rios de dinheiro. Precisava-se de um salão, de um lugar de encontro para a grande gente. Nós não tínhamos palácios, não havia educação mundana... Acrescia a falta de cultura das altas classes. Sem que, em geral, tivessem recebido um forte preparo na mocidade, a gente rica, os plantadores, só podiam compreender a música e a ópera, no teatro - lugar em que pouco se fala. Era preciso uma casa elegante para poli-los com o auxílio da arte. A ópera tem essa vantagem, é fácil, compreensível, popular, por mais que os magnatas queiram-na fazer transcendente. Quem, durante vinte, trinta anos, esteve fora das cousas da inteligência, pode compreendê-la do pé para mão, sem esforço. A ideia do imperador, ao iniciar uma aristocracia, foi aproveitar esta música, para reuni-la, obrigá-la a se encontrar, se falar, a se casarem entre si. A nobreza não se fez e o Lírico degenerou em moda idiota, sempre com o mesmo espírito curto, mas sempre em roda de tolos. Procura por exemplo, hoje, na sala do Lírico os grandes nomes de 52. Onde estão? Onde param os filhos, os netos? Não se sabe... (BARRETO, 1956a, p. 99-101)
\end{abstract}

Essa última afirmação de Gonzaga sobre a geração de 52 seria contradita mais à frente, pois a personagem diria que em nada havia mudado a audiência do Teatro Lírico (em novo prédio): "São os mesmos fazendeiros sugadores de sangue humano; são os mesmos políticos sem ideias; são os mesmos sábios decoradores de compêndios estrangeiros e sem ideia própria; são os mesmos literatos à Otaviano [...]" (BARRETO, 1956a, p. 159). Essa aparente contradição justifica-se pela decadência daquela nobreza que se viu no início do século XX obrigada a dividir espaço com setores emergentes necessários à cidade letrada, setores que não deixavam de ser formados pelos filhos e netos daquela antiga elite cafeeira, que requisitavam para si a pompa da nobreza perdida. Não se podia mais, como no tempo do Império, comprar os títulos de nobreza, forjar brasões de família, mas o Teatro Lírico ainda era o espaço da diferenciação, da criação de barreiras: linguística - os espetáculos eram na maior parte de companhias estrangeiras; e social - marcada pelas áreas do teatro, pelos trajes e joias que eram ostentados. Essa nova elite era público e ao mesmo tempo espetáculo para os frequentadores das torrinhas ou para aqueles que sequer entravam no teatro, mas podiam vê-los desfilando pelos bondes e imediações do teatro. O Teatro era também sintoma de mudanças e da estagnação de uma escola da civilidade que falhara.

Como se tratava de um dos últimos encontros entre Gonzaga e Augusto é a hora do "discípulo" exercitar os métodos de análise propostos pelo mestre ao longo das inumeráveis conversas que tiveram. Uma pesquisa de campo que tem como locus o Teatro Lírico Fluminense, mas que não ignorava os arredores e as estrutura da cidade que dialogavam com aquele espaço: 
Acabado o jantar, Gonzaga de Sá vestiu-se pacientemente, carinhosamente. Íamos em cadeira de segunda classe, eu, por causa do traje, não podia acompanhar em primeira como ele queria; entretanto, abotoou-se, vez com que as calças caíssem com justeza sobre as botinas, amarrou bem a gravata, perfumou-se e fomos com antecedência comprar os bilhetes. Quando saltamos na porta do teatro, já começavam os carros a chegar. Em geral, os coupés traziam três pessoas e as vitórias seis, sem contar o nhonhô na boleia, ao lado do cocheiro. Havia um único palafreneiro para todos os carros. Logo que apontava no canto da Rua Senador Dantas, o pobre homem corria e seguia emparelhado ao veículo até o ponto justo de abrir a portinhola. Se, por acaso, um chegava trazendo o número normal de lotação e com ajudante de cocheiro próprio, causava pasmo. Era como se fosse uma carruagem de príncipe. Dos "ceroulas" é que saltava o grosso dos frequentadores. $\mathrm{E}$, ainda uma vez, eu me admirei que gente, que pagava vestidos e trajes tão caros, não pudessem vir em carruagens condignas e menos abarrotadas.

- Mete dó, não ofende, este luxo... (BARRETO, 1956a, p. 152)

Como se vê, a percepção crítica de Augusto começa antes de penetrar no Lírico Fluminense. A chave de leitura ópera e/ou circo da crônica de 1903 mostra-se útil no desvelamento das continuidades entre aqueles dois períodos de tempo: a necessidade do traje especial para entrar na primeira classe, o desfile de roupas luxuosas no bonde e as precárias e lotadas carruagens que chegavam ao teatro. Para o leitor da crônica fica a dúvida do motivo que não levou o romancista a aproveitar a percepção dos brasões da Monarquia e da República que compunham um sistema misto, reunindo as piores características de cada sistema - o espadagão e o dragão. Mas esse mesmo leitor pode articular uma leitura entre estes dois relatos, (re)inserindo a crônica na série ficcional de Lima Barreto. Assim, como Isaías Caminha, personagem de seu primeiro romance, precisou vir para Capital Federal e adentrar na redação de um jornal para perceber a falência do projeto democrático, Augusto Machado, conduzido por Gonzaga, penetra em áreas desconhecidas do teatro e por consequência da sociedade:

A sineta anunciou o espetáculo. Entramos. Poucas vezes fora eu ao antigo Pedro II e as poucas em que fui, assisti ao espetáculo das torrinhas; de modo que aquela sociedade brilhante que via formigar nas cadeiras e camarotes, de longe parecia revestida de uma grandeza que me intimidava. Debruçado na grade da galeria, as casacas corretas e os ricos vestuários das senhoras eram um deslumbramento aos meus pobres olhos; e, por não ser do meu gosto analisar os espetáculos que me agradam, aceitei aquela sociedade como deslumbrante grandiosa e brilhante. Contudo, vulgarmente, e muito, na entrada, parecia-me que aquelas damas, envoltas em capotes e outros agasalhos, tinham o ar de quem ia para o banho; enquanto, na sala, de colos nus, sob o rebrilho das luzes, surgiam-me como mármores de museus.

No Cassino, ao ver pelos camarotes aquelas conhecidas grandes damas estrangeiras, os galeões do México, rutilantes de joias e de sedas, também recebi igual impressão de grandeza, beleza e majestade. Consenti, depois de anos de ausência, em pisar no Lírico. Ia agora ver tudo aquilo mais de perto, graças a Gonzaga de Sá, graças à animação, ao reforço que ele trazia à minha humildade nativa. (BARRETO, 1956a, p. 152-153)

Os trajes daquela afamada elite e das grandes damas são vistos de perto. O que antes parecia luxo pelo jogo de luzes do teatro, que transformava as senhoras e damas em mármores de museu, agora se assemelha a trajes de banho. Augusto Machado cita também sua ida a outro espaço sofisticado, o Cassino, em que recebe 
igual impressão de grandeza, beleza e majestade. O Teatro e o Cassino eram o espaço do jogo social das elites dirigentes e aquela mesa de jogo, vista de mais perto, revelava seu aspecto mal-ajambrado:

\begin{abstract}
A representação ainda não começara. Damas conversavam com cavalheiros, à entrada dos camarotes. Eu ficava bem junto à fila direita. Vi algumas de perto e as cadeiras dos camarotes, que me pareceram bem inferiores às da sala de jantar da minha modesta casa. Notei-lhes o forro de reles papel pintado, o assoalho de tábuas de pinhos barato; alonguei o olhar pelo corredor e além de acanhados, julguei-os sujos, vulgares, a guiar os passos para lugares escusos. O teto sempre me intrigou. Com os seus varões de ferro atravessados, supus que se destinassem a trapézios e outras acrobacias. Ópera ou circo? Entretanto, eu estava no ponto mais elegante do Brasil; no ponto para que converge tudo que há de mais fino na minha terra.

Era para brilhar ali que nós todos brigávamos, matávamos, e roubávamos, por sobre oito milhões de quilômetros quadrados do Brasil. Não se acredita! Os músicos tinham acabado de afinar os instrumentos; dentro em pouco, o maestro chegou. 0 presidente apareceu no camarote e a orquestra atacou o hino nacional. Pusemo-nos de pé e, a começar propriamente a ópera, sentamo-nos a ouvi-la.

- Bela casa! disse eu ao ouvido de Gonzaga de Sá.

- Chic, rica! A metade não pagou entrada... (BARRETO, 1956a, p. 153-154)
\end{abstract}

A imagem dos trapézios que tanto intrigava os atores que se apresentavam no Lírico desvela o aspecto duplo daquele prédio: ópera e/ou circo. Como propusera Lima Barreto em sua crônica de 1903, essa duplicidade poderia ser utilizada como chave de leitura de alguns aspectos sociais do país naquele início de século. Nem ópera, nem circo. Nem sério, nem risível. Nem rico, nem pobre. Nem centro, nem periferia. Nem moderno, nem ultrapassado. As tentativas de civilizar e modernizar a cidade criavam estas duplicidades paradoxais: a mesma cidade que recebia espetáculos teatrais consagrados na Europa tinha um quarto de sua população vivendo em situação precária; a mesma sociedade que produziu revistas elegantes e que valorizava os preceitos da moda tinha que criar regras para que os menos favorecidos não andassem descalços no centro da cidade; escritores e intelectuais ligados à causa republicana, sempre dispostos a condenar o passado colonial, que elegiam Petrópolis (a cidade de D. Pedro) como símbolo da sofisticação e da distinção social; a elite do país que desfilava no Lírico suas roupas e joias, mas que ia ao teatro em meios de transporte precários e superlotados.

A visita ao teatro rendia a Augusto Machado essa constatação - o teatro um microcosmos da cidade. A cidade, por sua vez, dinamizando a inserção do país no mundo da técnica e do capital. A aparência de modernidade e sofisticação do teatro encontrava seu correlato nas reformas superficiais e de fachada que aconteciam na cidade. Uma inserção problemática que insistia em apontar as marcas do passado, do atraso e da dependência.

\title{
Referências
}

ASSIS, Machado. Esaú e Jacó. São Paulo: Ática, 1999. 
Crônicas completas de Machado de Assis. Disponível em:

<http://www.dominiopublico.gov.br>. Acesso em: 24 jun. 2008.

AZEVEDO, Arthur. O Theatro: crônicas de Arthur Azevedo (1894-1908). Organização Larissa de Oliveira Neves e Orna Messer Levin. Campinas: Ed. Unicamp, 2009.

O Rio de Janeiro em 1877. Disponível em:

<http://virtualbooks.terra.com.br/freebook/port/O_Rio_de_Janeiro_em_1877.htm>. Acesso em: 16 set. 2010.

BARRETO, Lima. Vida e Morte de M.J. Gonzaga de Sá. São Paulo: Brasiliense, 1956a. Diário Íntimo. São Paulo: Brasiliense, 1956b.

Toda crônica: Lima Barreto; organização Beatriz Resende e Rachel Valença. Rio de Janeiro: Agir, 2004.

DUNLOP, Charles. Os meios de transportes do Rio antigo. Rio de Janeiro: Ministério dos Transportes, Serviço de Documentação, 1972.

EDMUNDO, Luís. O Rio de Janeiro do meu tempo. Brasília: Edições do Senado Federal, 2003.

Jacquemont, Victor. In: PRADO, Décio de Almeida. História concisa do teatro brasileiro: 1570-1908. São Paulo: Edusp, 2003.

LIRA, Heitor. História de Dom Pedro II, Fastígio, 1825-1891. Prefácio, iconografia e índices de Alexandre Eulálio. São Paulo: Ed. USP, 1977.

MACEDO, Joaquim Manoel de. Memórias da rua do ouvidor. Brasília: Editora da UNB, 1988.

NABUCO, Joaquim. João Caetano. In: Escritos e discursos literários. Rio de Janeiro: Garnier, 1901. p. 27-33. Disponível em: <http://www.brasiliana.usp.br>. Acesso em: 19 maio 2010.

\section{Imagens}

Teatro Lírico Fluminense. Disponível em: <http://www.ctac.gov.br>.

Retrato de Louis Moreau Gottschalk. Fonte:

<http://en.wikipedia.org/wiki/Louis_Moreau_Gottschalk>.

Rosine Stoltz. Foto de Nadar. Fonte: <http://fr.wikipedia.org/wiki/Rosine_Stoltz>. 


\section{Title}

Drama and Cultural Lag in the View of Lima Barreto

\section{Abstract}

In the novel Vida e Morte de Morte de M. J. Gonzaga de Sá [Life and Death of M. J. Gonzaga de Sá], Brazilian author Lima Barreto sets up an important discussion on the relation between the theater produced in the city of Rio de Janeiro (from mid nineteenth century to the beginning of the twentieth century) and its supposed civilizing and modernizing role that Brazilian intellectuals assigned to it at that time. The aim of this paper is to closely examine these assumptions on the role of the theater in order to compare them to Lima Barreto's critical view, in which the author reveals the temporary nature of Brazilian's peripheric and dependant modernity. Thus, I also take a close look on passages from Barreto's Diário Íntimo [Personal Journal] and on a few of his chronicles that have similar questions to the ones brought up by Vida e Morte.

\section{Keywords}

Lima Barreto. Theater and modernity. Theater and civilizing habits.

Recebido em 02.05.2011. Aprovado em 11.07.2011. 